\title{
Undergraduates' Use of Libraries in Federal Universities in South-West, Nigeria
}

\author{
${ }^{1}$ Onuoha, Uloma Doris, ${ }^{2}$ Subair, Mosunmade O. \\ ${ }^{1,2}$ Department of Information Resources Management Babcock University, Nigeria
}

\begin{abstract}
This paper investigated library use among undergraduates in Federal Universities in South-West, Nigeria with the objectives of determining frequency of library visits, extent of use of library resources and challenges faced when using the library. The descriptive survey design was used for the study. The population was made up of 2086 students in the third year of study. Multi-stage sampling technique was used for selecting a sample size of 633. Data was collected with the aid of a questionnaire and analysed using frequency distribution and percentage counts. Findings from the study revealed that majority of the respondents use the university library. Books and help desk service were found to be heavily utilised. Lack of relevant books and breakdown of internet facilities were, however, found to be the greatest challenges faced when using the library. The study concludes by noting that the university library is responsible for meeting the information needs of its community and as such recommends that university libraries endeavour to provide relevant and up-to-date books to attract and retain users. Although the internet may not be the primary purpose for using the library, there is, however, need for libraries to maintain internet facilities considering its worth in information provision.
\end{abstract}

\section{Introduction}

The relevance of the library in the age of technology has been a matter of debate in recent times. While the debate rages on within and outside the academia, Abosede \& Ibikunle (2011) note a growing concern over students' use of the libraries in higher institutions in Nigeria. Studies by Osinulu (1998); Akin \& Ajayi (2008), bring to light the declining use of libraries within the university system. For researchers like Oyesiku \& Oduwele (2004); Oluwadare (2006); Yusuf \& Iwu (2010), even though libraries are being used, they are, however, reduced to seasonal places of reading as most students make use of the library when preparing for examinations. In situations where libraries were seen to have recorded high patronage, evidence abound that users face a variety of challenges including, but not limited to, difficulty in catalogue use, obsolete materials and poor shelving (Okere \& Onuoha, 2008; Amkpa 2000).

In the face of all these, Franscotti, et al. (2007) argue that libraries are trying to re-invent themselves to be more appealing. No wonder then, that many libraries within an outside Nigeria now go beyond the provision of print information resources to the provision of electronic information sources as well as employing ICT use in different areas of services. Nevertheless, Fowowe (1989) notes that a library can best fulfil its function by pursuing a policy of evaluation. In line with this, Martin (1976) as cited by Agboola \& Bamigboye (2011) states that library use is an important measure of output of services provided by libraries. An understanding of library use would, therefore, aid the planning of future services that could encourage library patronage, hence, the need for the present study.

\section{Statement of the Problem}

The responsibility of supporting learning and research within the university environment, through the provision of information materials has always being that of the university library. However, literature and observation suggest a decline in library usage as some students may not be taking advantage of the resources provided by the university library. Where such is the case, students may find it difficult coping with the rigours of academics. It is in the light of the above, that the present study investigates library use among undergraduates in federal universities in South-West, Nigeria.

\section{Objectives of the study}

The purpose of the study was to examine library usage among undergraduates in federal universities in Nigeria. Specifically, the study sought to:

1. determine the frequency at which undergraduates visit the university library;

2. ascertain the extent to which undergraduates make use of library resources;

3. identify the challenges faced by undergraduates when using the university library. 


\section{Literature review}

A conducive environment in terms of learning and research has often being associated with the use of libraries. The importance of libraries in the educational system is re-echoed by Lance, Rodney \& HamiltonPennel (2000) as cited in Aanu \& Olatoye (2011) who reviewed literature and discovered that students in schools with good library resources and full time librarians perform at high levels than students in schools with minimal or no library resources. No wonder then, that library use has been the subject of many studies.

Osinulu (1998) investigated patterns of library use at Ogun State University, Nigeria, by scrutinizing user records and data, the result of that study revealed low use of library and subsequently, low use of library services, which was attributed to lack of awareness. Akin \& Ajayi (2008) while studying the use of Federal University of Technology Library in Nigeria equally found out that out of 475 students, only 82 use the library on daily basis. A similar study by Oyesiku \& Oduwele (2004) revealed that students use the library mostly during examinations to study and to do class assignments. The study further revealed that the library collections were inadequate to meet users' demands. Okiy (2000) went further to assesses students and faculty use of academic libraries in Nigeria with particular reference to Delta State University, Abraka. Although students constituted the majority of the users, most respondents were found to use the library 2-3 times a week or daily. The study further revealed that textbooks are the most frequently used materials with 98 (63.6\%), followed by reference materials at $25(16.2 \%)$.

A study of the accessibility and use of the Federal Polytechnic Ado-Ekiti, Nigeria by Oluwadare (2006) revealed that the library was well used. This was affirmed by $100(52.6 \%)$ of the respondents who claimed to use the library whenever they want to read. Among the study's respondents, 49 (25.7\%) claim that they hardly use the library because materials in the library do not meet their needs. In related studies, low use of libraries was, however, established by Haglund \& Olsson (2008) who conducted observational studies at three universities in Stockholm, Sweden. The result of the study confirmed that most researchers used Google for everything and were confident that they could manage their information needs on their own. The study further confirmed that researchers had very little contact with the library, and little knowledge about the value librarian competence could add.

Yusuf \& Iwu (2010) established in their statistical study in Covenant University that students utilise the online public access catalogue more than the manual catalogue. In related studies, Onuoha, Ikonne, \& Madukoma (2013) while studying library use and research productivity of postgraduate students, concluded that postgraduate students place more importance on books (print) followed closely by internet provision and electronic journals. Udo-Anyanwu, Jeff-Okafor \& Mbagwu (2012) compared the use of library resources between students at Imo State University and Alvan Ikoku Federal College of Education. They grouped library materials into three broad categories namely: oral information; printed information and digitised information. The study established that in both libraries, students utilised printed information more than digitised information and oral information was never used in any of the libraries. The study also identified insufficient library space as the greatest problem facing the use of both libraries.

Kamanda (1999) in a study at the East African School of Library and Information Science Library, Makerere University, Uganda observed that more than half of the students experience problems in locating library information materials. The author noted that majority of the students either located materials through browsing the shelves or sought assistance from library staff, but did not make full use of the card catalogue. Nimsomboon \& Nagata (2003), in a study of Thammasat University Library also catalogued a list of problems encountered while using the library, ranging from inadequacy and outdated resources (books, journal, newspaper, computer terminals); and shelving problem as the users cannot find the books on shelves, though they are found in online public access catalogue. A more recent study by Ogunniyi \& Efosa (2010) on catalogue use by students of Adeyemi College of Education, Ondo concluded that the problem of catalogue use is associated with lack of knowledge on how to use the library catalogue as indicated by majority of the respondents $211(52.7 \%)$.

\section{Research methodology}

The descriptive survey research design was used for the study. The population was made up of two thousand and eighty six (2086) third year students. The choice of limiting the study to third year students was done on the consideration that third year students would have spent enough time using the university library and as such will be in a good position to assess it. Multi-stage sampling technique was used for selecting the sample for the study. Simple random by balloting was firstly used for selecting three out of the six federal government owned universities in South-West, Nigeria. Two faculties were, thereafter, selected randomly from the three universities, out of which four departments common to the selected faculties were purposively chosen. Finally, stratified random sampling was used for selecting $30 \%$ as respondents for the study. A questionnaire was used for data collection and data collected were analysed using frequency and percentage counts. 
Table 1: Selected universities; faculties; department; population and sample size

\begin{tabular}{|c|c|c|c|c|}
\hline Universities & Faculty & Departments & Population & Sample size $(30 \%)$ \\
\hline \multirow{5}{*}{$\begin{array}{l}\text { University } \\
\text { of Ibadan }\end{array}$} & \multirow[t]{3}{*}{ Science } & Biochemistry & 86 & 26 \\
\hline & & Microbiology & 98 & 29 \\
\hline & & Physics & 74 & 22 \\
\hline & \multirow[t]{2}{*}{ Humanities } & Communication Arts & 85 & 26 \\
\hline & & Linguistics & 73 & 22 \\
\hline \multirow{5}{*}{$\begin{array}{l}\text { University } \\
\text { of Lagos }\end{array}$} & \multirow[t]{4}{*}{ Science } & Biochemistry & 116 & 35 \\
\hline & & Microbiology & 101 & 30 \\
\hline & & Physics & 82 & 25 \\
\hline & & Geology & 60 & 18 \\
\hline & Humanities & Communication Arts & 92 & 28 \\
\hline \multirow{9}{*}{$\begin{array}{l}\text { Obafemi } \\
\text { Awolowo } \\
\text { University }\end{array}$} & \multirow[t]{4}{*}{ Science } & Biochemistry & 110 & 33 \\
\hline & & Microbiology & 116 & 35 \\
\hline & & Physics & 85 & 26 \\
\hline & & Geology & 68 & 20 \\
\hline & \multirow[t]{4}{*}{ Humanities } & Communication Arts & 91 & 27 \\
\hline & & Linguistics & 75 & 23 \\
\hline & & English & 98 & 29 \\
\hline & & History & 83 & 25 \\
\hline & TOTAL & & 2086 & 633 \\
\hline
\end{tabular}

\section{Presentation of findings}

Figure 1: Institutional distribution of respondents

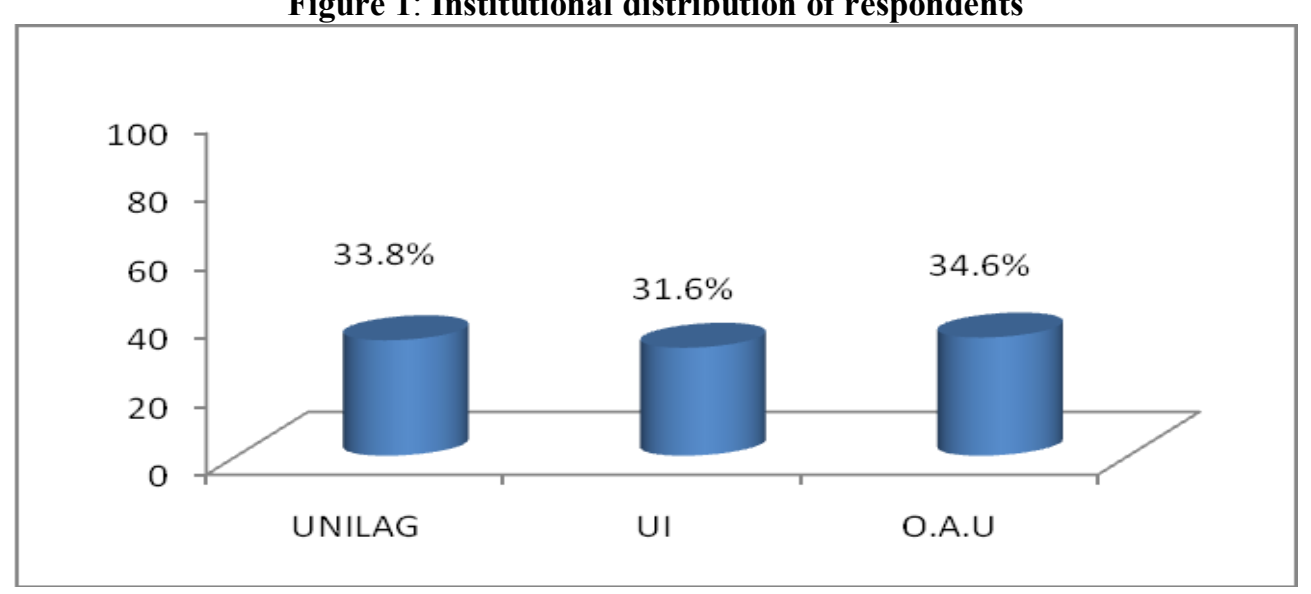

Figure 1 shows the percentage of respondents in the universities selected for this study. Obafemi Awolowo University had the highest number of respondents followed by University of Lagos.

Figure 2: Frequency of library visits

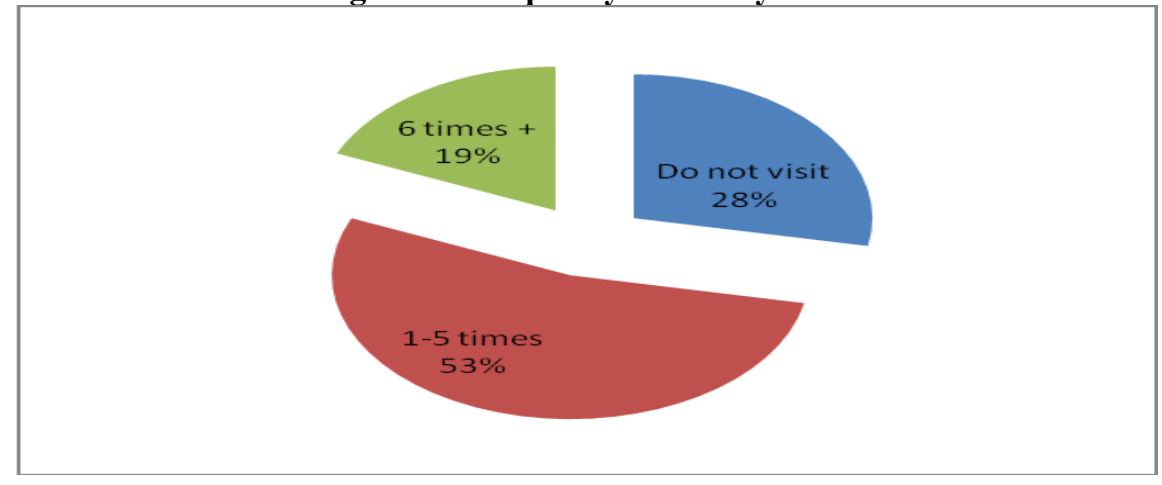


Finding from Figure 2 indicates that majority of the respondents do visit the library. 53\% actually claim to do so between 1-5 times a week, $19 \%$ claim they visit the library up to 6 times a week, while $28 \%$ affirmed that they do not visit the library.

Table 2: Use of library resources

\begin{tabular}{|l|l|l|l|l|l|l|}
\hline Items & D & W & M & Q & A & NU \\
\hline Help desk & $319(50.4)$ & $54(8.5)$ & $54(8.5)$ & $62(9.8)$ & $14(2.2)$ & $130(20.5)$ \\
\hline Textbooks (print) & $243(38.4)$ & $104(16.4)$ & $28(4.4)$ & $94(14.8)$ & $82(13.0)$ \\
\hline Dictionaries & $178(28.1)$ & $126(19.9)$ & $68(19.9)$ & $88(13.9)$ & $62(9.8)$ & $82(13.0)$ \\
\hline Internet facility & $131(20.7)$ & $98(15.5)$ & $40(6.3)$ & $82(13.0)$ & $34(5.4)$ & $111(17.5)$ \\
\hline Loaning materials & $116(18.3)$ & $76(12.0)$ & 0.00 & $60(9.5)$ & $28(4.4)$ & $35(39.2)$ \\
\hline Photocopy & $116(18.3)$ & $98(15.5)$ & $42(6.6)$ & $136(21.5)$ & $40(6.3)$ & $201(31.8)$ \\
\hline Current awareness & $102(16.1)$ & $34(5.4)$ & $68(10.7)$ & $76(12.0)$ & $54(8.5)$ & $299(47.2)$ \\
\hline Encyclopaedia & $96(15.2)$ & $118(18.6)$ & $48(7.6)$ & $80(12.6)$ & $34(5.4)$ & $257(40.6)$ \\
\hline Indexes/abstracts & $68(10.7)$ & $28(4.4)$ & $108(17.1)$ & $34(5.4)$ & $14(2.2)$ & $381(60.2)$ \\
\hline Thesis/dissertation & $48(7.6)$ & $56(8.8)$ & $40(6.3)$ & $20(3.2)$ & $102(16.1)$ \\
\hline Digital collections & $48(7.6)$ & $68(10.7)$ & $34(5.4)$ & $74(11.7)$ & $62(9.8)$ & $367(58.0)$ \\
\hline Journals & $48(7.6)$ & $54(8.5)$ & $42(6.6)$ & $108(17.1)$ & 0.00 & $347(54.8)$ \\
\hline CD-Rom & $42(6.6)$ & $48(7.6)$ & $74(11.7)$ & $54(8.5)$ & $48(7.6)$ \\
\hline Lamination & $34(5.4)$ & $82(13.0)$ & $62(9.8)$ & $186(29.4)$ & $62(9.8)$ \\
\hline Binding & 0.00 & $28(4.4)$ & $82(13.00$ & $192(30.3)$ & 0.00 \\
\hline Projector & 0.00 & 0.00 & $14(2.2)$ & $48(7.6)$ & $381(60.2)$ \\
\hline
\end{tabular}

Key: D=daily, W=Weekly. M=Monthly, $Q=$ Quarterly, A=Annually, NU=Never used.

Table 2 details respondents' use of library resources. From the table, it is obvious that the help desk is heavily utilised as affirmed by $319(50.4 \%)$ of the respondents who claim to use the library daily. Only 130 $(20.5 \%)$ of the respondents also claim never to have it. Textbooks were also found to be heavily used as attested to by $243(38.4 \%)$. Although the use of textbooks scored lower than the use of help desk on daily usage it, however, surpassed the use of help desk when usage in terms of weekly, monthly, quarterly and annually were all taken into consideration. Of all library resources, textbooks recorded the lowest rating under "never used", an indication that most of the respondents do use textbooks. Dictionaries and Internet facilities followed on daily use with $178(28.1 \%)$ and 131(20.7) respectively.

Other library resources such as digital collections, thesis/dissertations, journals and CD-Rom use did not fare so well with daily use as low as 48 (7.6\%) and $42(6.6 \%)$. The rating given to these items under "never used", were equally very high. The projector as a library resource had the least rating in terms of use as it was neither used daily nor weekly and also had the highest ratings for never used library resource.

Table 3 Challenges faced when using the library

\begin{tabular}{|l|l|l|}
\hline Challenges & Frequency & Percentage \\
\hline Lack of relevant books & 473 & 74.7 \\
\hline Constant breakdown of internet facilities & 379 & 59.9 \\
\hline Obsolete library equipment & 319 & 50.4 \\
\hline $\begin{array}{l}\text { Inadequate knowledge on how to use the } \\
\text { library catalogue }\end{array}$ & 291 & 46.0 \\
\hline Related subjects are not properly linked & 175 & 27.6 \\
\hline
\end{tabular}

Findings from table 3 reveal challenges faced by respondents when using the library. As affirmed by $473(74.4 \%)$ of the respondents, the greatest challenge faced when using the library is lack of relevant books. This is followed by breakdown of internet facilities. The least problem was identified as related subjects not being properly linked.

\section{Discussion of findings}

The findings of this study present a clear pattern of library use among undergraduates in federal universities in South West, Nigeria. From the findings, it is obvious that undergraduates still make use of the university library. The finding is this case disagrees with the findings of Osinulu (1998) and Akin \& Ajayi (2008) whose studies revealed low level of library use. It is, however, in agreement with the findings of Okiy (2000) whose study showed that students still make good use of the university library. This implies that the library is still relevant in today's academic environment.

From the findings of this study, it was evident that undergraduates highly utilise the help desk. The finding is in agreement with Kamanda's (1999) study, in which findings revealed that students sought assistance from library staff. The findings may be attributed to the fact, that the help desk serves a myriad of functions in Nigerian libraries being often merged with circulation services. The high use of the help desk may also be a matter of concern for libraries as it could also be an indication that users are having difficulty using the library. 
The use of text books and dictionaries were well acknowledged by the respondents as they came next to help desk. The importance attached to text books is reflected in its' rating under "never used" where it received the lowest score. This shows that almost every one who utilises the library makes use of library books. The finding is in agreement with the findings of Okiy (2000) which established that text books and reference materials were the most used library resources. It is also in agreement with the study of Onuoha, Ikonne \& Madukoma (2013) which affirmed that postgraduate students place more importance on books than any other library resource. The implication is that textbooks (print) are essential to library users whether at the undergraduate or graduate level. From the ratings, it was obvious that though important, the internet was certainly not considered as the most important resource in the library. The reason why textbooks for instance are used more than internet facility could be attributed to the fact that students may have access to internet through other sources such as their mobile phones or modems. Other resources such as thesis/dissertations, digital collections, journals, library catalogue, lamination, binding and projector received low use ratings which corroborates the findings of Osinulu (1998) that library services are hardly used due to lack of awareness.

This study also established that undergraduates in Federal Universities in South-West, Nigeria, face some challenges while using the library. The greatest challenge identified was lack of relevant books followed by constant breakdown of internet facilities. The finding is in partial agreement with Nimsomboon \& Nagata (2003) who discovered the major problem facing students' use of the library as inadequate books and outdated resources. The finding, however, disagrees with Udo-Anyanwu, Jeff-Okafor \& Mbagwu (2012) whose study identified insufficient space as the greatest problem facing library use.

\section{Conclusion}

There is no doubt that the university library is relevant even in the face of technological advancement where information can be sourced from outside the library. The library still has the obligation to meet the information needs of its' community by ensuring the provision of relevant information materials and offering personal assistance to users in order to ensure optimal use of library materials.

\section{Recommendations}

Based on the findings, the following recommendations are made:

1 Libraries in federal universities in South-West Nigeria should endeavour to provide relevant and up-todate books to attract and retain more users in the library. This is particularly important considering that books were found to be highly used and at the same time the greatest area of challenge for library users.

2 Considering the fact that some library resources are poorly used, there is need to evaluate their importance in libraries to ascertain if there is need to create more awareness or re-package the services/resources.

3 While using the internet may not be the most important reason for using the library, there is need for libraries to maintain internet facilities to serve those who do come to the library to use it considering its strength in information provision.

4 The libraries in the studied universities should also ensure that adequate training is given to students on the use of the library catalogue to ensure optimal use library resources.

\section{References}

[1] Aanu, E. M \& Olatoye, R. A. (2011) Use of library resources, study habit and science achievement of junior secondary school students Educational Research 2(7):1265-1269

[2] Abosede, A. T \& Ibikunle, O. O. (2011) Determinants of library use among students of agriculture: A case study of Lagos State Polytechnic. Available @http://unllib.unl.edu/LPP/abosede-ibikunle.htm

[3] Akin, A. O. \& Ajayi, P. O. (2008) Students' utilization of academic libraries in Nigeria: A case study of Federal University of Technology, Akure between year 2001-2005. Asian Journal of Information Technology 7(5):172-174

[4] Amkpa, S. A. (2000). Students' use of University of Maiduguri Library: An evaluative study. Gateway Library Journal 2 \& 3:70-80.

[5] Fowowe, S.O. (1989). Students' use of an academic library: A survey at the University of Ilorin Libraries. Nigerian Library and Information Science Review 7 (1): 56

[6] Frascotti, J., Levenseler, J., Weingarten, C., \& Wiegand, K. (2007). Improving library use and information literacy at Caritas Charles Vath College. An interdisciplinary qualifying project report submitted to the Faculty of Worcester Polytechnic Institute. B.Sc. Thesis. KAL, 0704; IQP division: 51. Available@ @ http://www.wpi.edu/Pubs/E-project/Available/E-project-030107-103835/

[7] Haglund, L . \& Olsson, P. (2008) The impact on university libraries of changes in information behaviour among academic researchers: A multiple case study. The Journal of Academic Librarianship 34 (1):52-59

[8] Martins, L.A. (1976). User studies and library planning Library Trend. 24(3): 483-496

[9] Nimsomboon, N. \& Nagata, H. (2003). Assessment of library service quality at Thammasat University Library System. Available (a) http://www.kc.tsukuba.ac.jp/div-comm/pdf/report0403.pdf

[10] Ogunniyi, S. O. \& Efosa, F. E. (2010) Use of library catalogue by students of Adeyemi College of Education, Ondo. Tincity Journal of Library, Archival and Information Science 1(2):47-51

[11] Okere, S. \& Onuoha, U. D. (2008) Academic staff assessment of accessibility and usefulness of library resources to teaching and research: A case of Babcock University. Journal of Language and Development 5:47-58 
[12] Okiy, R. B. (2000). Assessing students and faculty use of academic libraries in Nigeria:The study of Delta State University Abraka. Frontiers of Information and Information Science 1(1): 65-75

[13] Oluwadare, I. B. (2006). Accessibility and use of library resources by part-time students: A case study of the Federal Polytechnic, Ado-Ekiti, Nigeria. Library Review, 55(2), 148-156.

[14] Onuoha, U.D., Ikonne, C. N \& Madukoma, E. (2013) Perceived impact of library use on the research productivity of postgraduate students at Babcock University, Nigeria IOSR Journal of Research \& Method in Education 1 (1):11-16

[15] Osinulu, L. F. (1998). Library use in Ogun State University: A survey. Gateway Library Journal 1 (2): 81-87.

[16] Udo-Anyanwu, A. J., Jeff-Okoroafor, I. \& Mbagwu, I. (2012) Information seeking behaviour of students in the use of library resources at the libraries of Imo State University and Alvan Ikoku Federal college of Education, Owerri. Jewel Journal of Librarianship 4:24-29

[17] **Ugah, A. D. (2007) Evaluating the use of university libraries in Nigeria: A case study of Michael Okpara University of Agriculture, Umudike. Library philosophy and practice

[18] Yusuf, F., \& Iwu, J. (2010). Use of academic library: a case study of Covenant University,Nigeria. Available@ http:// www.whiteclouds.com

[19] Zeynep, F. (2007). Service Quality of University Library: A Survey Amongst Students at Osmangazi university and Anadolu University. Istanbul University Econometrics and Statistics e-Journal. 5.1: 1-19 also available@ http://eidergisi.istanbul.edu.tr/sayi5/iueis5m1.pdf accessed on 8/7/08 